Br Heart J 1988;60:165-8

Case reports

\title{
Management of a patient with Wilms's tumour extending into the right heart chambers: a case report and a review of other published reports
}

\author{
T M HUNT, R K FIRMIN, M J S JOHNSTONE* \\ From the Sub-Regional Cardiothoracic Unit, Groby Road Hospital; and ^Department of Surgery, Leicester \\ Royal Infirmary, Leicester
}

SUMMARY Wilms's tumours that extend by direct intravascular spread into the right side of the heart are rare. A case of such a tumour was diagnosed by ultrasound. A one stage resection was performed on cardiopulmonary bypass and with profound hypothermic circulatory arrest. It was followed by adjunctive chemotherapy and radiotherapy. The child was alive and tumour free 18 months later. A review of 17 other similar cases indicated that multimodal treatment is justified in patients with extensive intravascular spread of Wilms's tumours.

There have been only 17 cases of right atrial extension of Wilms's tumour reported in English this century. ${ }^{1-14}$ Such cases used to be regarded as inoperable. Advances in surgical techniques and adjunctive treatment have made surgical excision possible and worth while even when the disease is extensive. We report the management of a case of this type of Wilms's tumour which we believe to be the first reported from Britain, and we review earlier cases.

\section{Case report}

A five and a half year old boy was admitted with a history of lethargy and diarrhoea for three weeks and generalised abdominal pain and anorexia for one week.

On examination he was unwell with a tachycardia, tachypnoea, and leg oedema. His blood pressure was $110 / 70 \mathrm{~mm} \mathrm{Hg}$ but the jugular venous pressure was raised with a prominent "a" wave. A systolic ejection murmur was audible at the left sternal edge. There were signs of a right pleural effusion. The abdomen was distended with considerable hepatomegaly, a mass in the left upper quadrant, and ascites.

Investigations showed a haemoglobin concentraRequests for reprints to Mr R K Firmin, FRCS, Sub-Regional Cardiothoracic Unit, Groby Road Hospital, Groby Road, Leicester LE3 9QE. tion of $142 \mathrm{~g} / 1$, white cell count of $15.8 \times 10^{9} / 1$, and platelet count of $40 \times 10^{9} / 1$. Coagulation tests showed an International Normalised Ratio of $2 \cdot 1$. The serum activity of alanine aminotransferase was raised (1266 IU/1). Bilirubin and renal function were normal.

Chest $x$ ray confirmed a right pleural effusion and enlarged cardiac silhouette. Ultrasound scan confirmed the presence of ascites and a pleural effusion, and showed a grossly enlarged left kidney with distorted calyces. The inferior vena cava was occluded by tumour or thrombus that extended into the right atrium and prolapsed into the right ventricle with each cardiac cycle. A diagnosis of Wilms's tumour originating in the left kidney and extending to the inferior vena cava and right heart was made on the basis of this investigation.

Computed tomography showed that the renal mass originated in the upper pole and showed dilatation of the inferior vena cava. It did not detect extension of tumour into the right atrium. The lung fields were clear. Venography showed obstruction of the inferior vena cava and iliac veins above the internal iliac vessels with drainage via anastomotic channels to the vertebral venous system.

Real time cross sectional echocardiography confirmed the intracardiac tumour and suggested that it was mobile (figure). A skeletal survey was normal. 


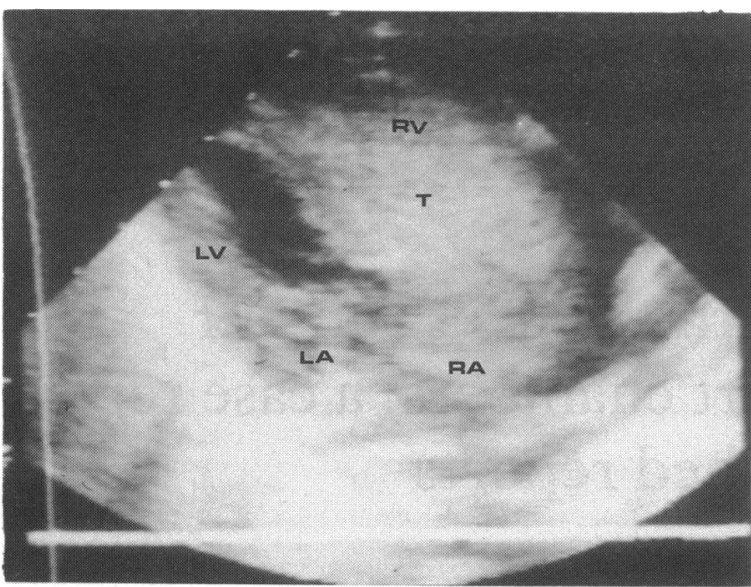

Figure Echocardiogram (apical four chamber view) showing tumour within right atrium prolapsed through to the right ventricle. $T$, tumour; $R V, R A, L V, L A$, heart chambers.

\section{OPERATION}

A cardiac team removed the intravascular tumour and an abdominal team performed the radical nephrectomy. A routine cardiac surgical anaesthetic was given. Intravascular lines were placed to monitor arterial blood pressure, pressure in the inferior and superior caval veins, and to administer fluid. A urinary catheter was inserted. Temperature probes were placed in the nasopharynx, oesophagus, and on the tympanic membrane.

A median sternotomy was performed, the presence of a large tumour mass in the right atrium was confirmed, and the heart was prepared for cardiopulmonary bypass. The incision was then extended into a full midline laparotomy and the left renal tumour was mobilised by the second team of surgeons. The inferior vena cava, left renal vein, adrenal vein, and testicular vein all had clot and tumour extending into them. The liver was grossly congested but showed no evidence of metastases. The testicular vessels were ligated distal to any macroscopic tumour and the ureter was divided at the pelvic brim.

During the final part of the dissection haemodynamic instability developed. The patient was therefore given heparin and cardiopulmonary bypass was established with one right atrial venous cannula and an ascending aortic return. While the patient was cooled to $15^{\circ} \mathrm{C}$ the radical left nephrectomy was completed. The specimen weighed $260 \mathrm{~g}$. The aorta was cross clamped, the circulation was arrested, and the patient was exsanguinated. The right atrium and infrahepatic vena cava were opened. The intracardiac tumour was mobile but the intracaval portion was adherent and required careful instrumentation from above and below to free it. Fogarty extraction of distal venous thrombosis to the iliac veins was. performed and the right renal vein and both pul $\overrightarrow{\bar{c}}$ monary arteries were checked for clearance. The inferior vena cava and right atrium were repaired an $\$$ cardiopulmonary bypass was re-established by bicaval cannulation after 37 minutes of circulatoryo arrest. The patient was rewarmed and came off bypass without difficulty. The chest and abdomen ${ }^{\text {s }}$ were closed routinely with drainage. There was noo difficulty in obtaining haemostasis after reversal of the heparinisation with protamine sulphate.

The patient made an excellent postoperative recovery. Histopathology confirmed the diagnosis of Wilms's tumour of the favourable histological type ${ }_{i}$ Postoperative radiotherapy was given as well as oneyear of chemotherapy. The patient was alive, well, and disease free 18 months after operation.

\section{Discussion}

Direct extension of Wilms's tumour into the right $\stackrel{\text { की }}{+}$ heart cavities is rare. In one study it occurred in $0.7 \% \vec{\oplus}$ of cases of Wilms's tumour. ${ }^{15}$ The table summariseso the clinical features of all 17 reported cases.

Accurate preoperative diagnosis of the extent of the tumour is required to plan the management of each case. Assessment of the inferior vena cava is important in all cases of renal tumour, and before resection of hepatic tumours also, to minimise the risk of tumour embolism at operation and allow for complete resection. The upper limit of intravascular spread needs to be defined. If the caval veins areo involved the possibility of extension of the tumour to the heart must be investigated. This avoids the risk that extension to the heart will be recognised only? when abdominal surgery is under way and when 3 appropriate facilities for cardiothoracic operation may not be available. Similarly, it is important to assess the inferior vena cava for distal extension in cases of suspected right atrial tumour. ${ }^{7}$

In nine of the 17 reported cases an accurateo diagnosis was not made before the initial operation was planned (table). One patient presented with ano abdominal Wilms's tumour and the inferior venan cava was not investigated before operation. ${ }^{4}$ TheN inferior vena cava was known to be affected in two cases but no further elective investigations were undertaken to define the upper limit of intravascular extension. ${ }^{38}$ In the other eight cases, and in the cases reported here, the extent of the tumour was recogn ised before operation. Angiography has been recommended for assessment of the intravascular spread of tumours, ${ }^{8914}$ but this invasive procedure risks, precipitating tumour embolism or cardiovascular $\frac{\rho}{\sigma}$ decompensation in patients whose condition is un- 
stable because the heart is affected. ${ }^{10}$ Newer imaging techniques, particularly ultrasound, are useful for non-invasive investigation. ${ }^{56111315}$ We support the use of ultrasonography, which gave better results than computed tomography in our patient.

Several surgical options are available (table). Although staged resection has been performed, ${ }^{310}$ a one stage procedure is more desirable. If the tumour has extended into the right heart, cardiopulmonary bypass is usually required. We used cardiopulmonary bypass with profound hypothermia and circulatory arrest. A median sternotomy and midline laparotomy gave good access for both surgical teams, and avoids the risk of precipitating acute right heart obstruction when a patient with a mobile atrial tumour extension is turned. ${ }^{416}$ We performed the sternotomy first to allow rapid institution of cardiopulmonary bypass in the event of haemodynamic instability. Although the whole procedure could have been performed on bypass, we elected to do as much of the dissection as possible before heparinisation to avoid the risk of excessive bleeding. Circulatory arrest allowed controlled, accurate excision of the atrial and caval tumour in a bloodless field, and reduced the risk of tumour embolism. This phase of the resection was completed well within the safe period of circulatory arrest (45-60 minutes at $15 \mathrm{C})$. Cardiopulmonary bypass ${ }^{1314}$ and circulatory arrest ${ }^{310}$ have been used successfully before, but ours is the first reported case in which a planned one stage resection was performed on bypass, profound hypothermia, and circulatory arrest. This technique is similar to that reported in adults with renal cell carcinoma. ${ }^{1718}$

The prognosis of this type of Wilms's tumour is dependent on accurate preoperative assessment. Only two of the nine patients with an accurate preoperative diagnosis (including our case) have died $^{59}$ and one of these had unresectable primary disease. ${ }^{5}$ The other seven were alive and well between eight months and five years after operation. ${ }^{10-14}$ Of the nine with inadequate preoperative assessment, only one has survived for more than six months (three years six months).' Another review reported an increased complication rate when preoperative diagnosis was not accurate. This review included some of

Table Summary of the 17 earlier cases of Wilms's tumour extending into the right atrium

\begin{tabular}{|c|c|c|c|c|c|}
\hline $\begin{array}{l}\text { Ref } \\
\text { No }\end{array}$ & Authors (date) & Method of diagnosis & Operation & $\begin{array}{l}\text { Adjuv'unt } \\
\text { treatment }\end{array}$ & ()utcome \\
\hline 1 & $\begin{array}{l}\text { Nadas and } \\
\text { Ellison } \\
(1968) \\
(3 \text { cases })\end{array}$ & Necropsy & - & - & - \\
\hline 2 & $\begin{array}{c}\text { Anselmi et al } \\
(1970)\end{array}$ & Necropsy & 一 & - & - \\
\hline 3 & $\begin{array}{l}\text { Murphy et al } \\
(1973)\end{array}$ & Operation at time of nephrectomy & $\begin{array}{l}\text { CPB and circulatory arrest the next } \\
\text { day }\end{array}$ & $\begin{array}{l}\text { Chemotherapy and } \\
\text { irradiation }\end{array}$ & $\begin{array}{l}A \text { and } W 3 y \text { and } \\
6 \text { mnth }\end{array}$ \\
\hline 4 & $\begin{array}{l}\text { Utley et al } \\
\quad(1973)\end{array}$ & Operation at time of nephrectomy & $\begin{array}{l}\text { CPB and circulatory arrest after } \\
\text { abdominal closure }\end{array}$ & $\begin{array}{l}\text { Chemotherapy and } \\
\text { irradiation }\end{array}$ & Dicd $3 \mathrm{mnth}$ \\
\hline 5 & $\begin{array}{l}\text { Farooki et al } \\
\quad(1975)\end{array}$ & Echo and cardiac catheter & Unresectable primary & $\begin{array}{l}\text { Chemotherapy and } \\
\text { irradiation }\end{array}$ & Died \\
\hline 6 & $\begin{array}{l}\text { Farooki et al } \\
\quad(1976)\end{array}$ & $\begin{array}{l}\text { Echo } 6 \text { mnth after previous } \\
\text { nephrectomy }\end{array}$ & 1 stage resection with $\mathrm{CPB}$ & None specified & $\begin{array}{l}\text { Died } 6 \text { mnths } \\
\text { Ref } 11\end{array}$ \\
\hline 7 & $\begin{array}{l}\text { Aytac et al } \\
\quad(1976)\end{array}$ & $\begin{array}{l}\text { Cardiac catheter diagnosis of atrial } \\
\text { tumour. Extension from below } \\
\text { diaphragm only recognised at } \\
\text { operation. Wilms's tumour } \\
\text { diagnosed at necropsy }\end{array}$ & Atrial clearance only with (CPB & - & Died \\
\hline 8 & $\begin{array}{l}\text { Schullinger } \\
\text { et al (1977) }\end{array}$ & $\begin{array}{l}\text { Emergency cardiac catheterisation } \\
\text { after elective operation had been } \\
\text { planned }\end{array}$ & 1 stage resection with $\mathrm{CPB}$ & - & Dicd at operation \\
\hline 9 & $\underset{(1977)}{\text { Vaughan et al }}$ & Cardiac catheterisation & $\begin{array}{l}\text { I stage resection with }(. \mathrm{PB} \text { via } \\
\text { I } \mathrm{A} \text { incision }\end{array}$ & $\begin{array}{l}\text { Chemotherapy and } \\
\text { irradiation }\end{array}$ & Died $6 \mathrm{mnth}$ \\
\hline 10 & $\begin{array}{l}\text { Theman et al } \\
\text { (1978) }\end{array}$ & Cardiac catheterisation and C.I scan & $\begin{array}{l}2 \text { stages with C.PB and circulatory } \\
\text { arrest, and "interval } \\
\text { nephrectomy" after } 3 \mathrm{mnth}\end{array}$ & $\begin{array}{l}\text { Chemotherapy and } \\
\text { irradiation }\end{array}$ & $A$ and $W 19 \mathrm{mnth}$ \\
\hline 11 & $\begin{array}{l}\text { Slovis et al } \\
\quad(1978)\end{array}$ & Cardiac catheterisation and CI scan & No treatment described & $?$ & Alive $8 \mathrm{mnth}$ \\
\hline 12 & $\begin{array}{l}\text { Kolmannskog } \\
\text { et al (1979) }\end{array}$ & Cardiac catheterisation & 1 stage resection with no (.PB & Chemotherapy only & $A$ and $W^{\prime} 15 \mathrm{mnth}$ \\
\hline 13 & $\begin{array}{l}\text { Luck et al } \\
\text { (1982) } \\
(2 \text { cases })\end{array}$ & Echo and ultrasound & 1 stage resection with (CPB & $\begin{array}{l}\text { Chemotherapy and } \\
\text { irradiation }\end{array}$ & $\begin{array}{l}A \text { and } W 18 \text { mnth; } \\
A \text { and } W 20 \text { mnth }\end{array}$ \\
\hline 14 & $\begin{array}{l}\text { Schraut and } \\
\text { Chilcote } \\
\text { (1985) }\end{array}$ & Cardiac catheterisation & 1 stage resection with $C . P B$ & $\begin{array}{l}\text { Chemotherapy and } \\
\text { irradiation }\end{array}$ & $A$ and $W^{\prime} 5 y$ \\
\hline
\end{tabular}

CPB, cardiopulmonary bypass; $\mathrm{T}$ A, thoraco-abdominal; $\mathrm{A}$ and $\mathrm{W}$, alive, well, disease free; ("I', computed tomography. 
the reported cases reviewed in the present article. ${ }^{15}$

Intravascular extension of Wilms's tumour into the right side of the heart is rare. With modern imaging techniques, particularly ultrasound, it should be possible, however, to establish a diagnosis before operation. A planned one stage resection is then feasible after a midline sternotomy and laparotomy. Cardiopulmonary bypass, with or without hypothermic circulatory arrest, is needed for excision of the intravascular tumour. Complete surgical resection followed by adjunctive chemotherapy and radiotherapy may give long term, tumour free survival.

We thank Dr Rosemary Shannon for the postoperative oncological treatment of our patient and Dr A C Lamont, Dr R Leanage, and Dr K Simpson for their valuable contributions to the management of this case.

\section{References}

1 Nadas AS, Ellison RC. Cardiac tumors in infancy. $A m \mathrm{~J}$ Cardiol 1968;21:363-6.

2 Anselmi G, Suárez JA, Machado I, Moleiro F, Blanco $P$. Wilms' tumour propagated through the inferior vena cava into the right heart cavities. Br Heart $J$ 1970;32:575-8.

3 Murphy DA, Rabinovitch H, Chevalier L, Virmani S. Wilms' tumor in right atrium. Am J Dis Child 1973;126:210-1.

4 Utley JR, Mobin-Uddin K, Segnitz RH, Belin RP, Utley JF. Acute obstruction of tricuspid valve by Wilms' tumor. J Thorac Cardiovasc Surg 1973;66: 626-8.

5 Farooki ZQ, Henry JG, Green EW. Echocardiographic diagnosis of right atrial extension of Wilms' tumor. Am J Cardiol 1975;36:363-7.

6 Farooki ZQ, Green EW, Arciniegas E. Echocardiographic pattern of right atrial tumour motion. Br Heart J 1976;38:580-3.

7 Aytac A, Tuncali T, Tinaztepe K, Ikizler C, Saylam A.
Metastatic Wilms' tumor in the right atrium propagated through the inferior vena cava. Vasc Surg. 1976;10:268-74.

8 Schullinger JN, Santulli TV, Casarella WJ, MacMillan RW. Wilms' tumor: the role of right heart angio graphy in the management of selected cases. Ann Surg 1977;185:451-5.

9 Vaughan ED, Crosby IK, Tegtmeyer CJ. Nephro $\frac{\mathbb{D}}{2}$ blastoma with right atrial extension: pre-operativen diagnosis and management. $J$ Urol 1977;117:530-3.

10 Theman T, Williams WG, Simpson JS, Radford D $\vec{\rho}$ Rubin S, Stephens CA. Tumor invasion of the upper inferior vena cava: the use of profound hypothermis and circulation arrest as a surgical adjunct. $J$ Pediats Surg 1978;13:331-4.

11 Slovis TL, Cushing B, Reilly BJ, et al. Wilms' tumor to the heart: clinical and radiographic evaluation. $A m$ N Roentgenol 1978;131:263-6.

12 Kolmannskog S, Moe PJ, Besigye E, Sorlie D. Wilms tumor with extension to the right atrium. Med Pediat 9 Oncol 1979;6:313-6.

13 Luck SR, DeLeon S, Shkolnik A, Morgan E, Labotka R. Intracardiac Wilms' tumor: diagnosis and mantę agement. J Pediatr Surg 1982;17:551-4.

14 Schraut WH, Chilcote RR. Metastatic Wilms' tumor causing acute hepatic vein occlusion (Budd-Chiarfo syndrome). Gastroenterology 1985;88:576-9.

15 Nakayama DK, deLorimier AA, O'Neill JA, Norkool Pp D'Angio GJ. Intracardiac extension of Wilms' tumor A report of the National Wilms' Tumor Study. Ann? Surg 1986;204:693-7.

16 Paul JG, Rhodes DB, Skow JR. Renal cell carcinom保 presenting as right atrial tumor with successfup removal using cardiopulmonary bypass. Ann Surg్ 1975;181:471-3.

17 Marshall FF, Reitz BA, Diamond DA. A new technique for management of renal cell carcinoma? involving the right atrium: hypothermia and cardiag arrest. J Urol 1984;131:103-7.

18 Krane RJ, deVere White $R$, Davis $Z$, Sterling $R$ Dobnik DB, McCormick JR. Removal of renal cel, carcinoma extending into the right atrium using cardiopulmonary bypass, profound hypothermia and circulatory arrest. $J$ Urol 1984;131:945-7. 